\title{
Sjúkraflutningar á Íslandi
}

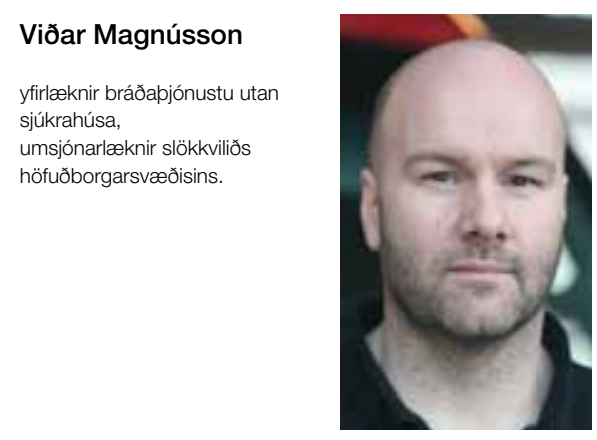

vidarmag@landspitali.is

Strjálbýli, fámenni og fjárskortur einkenna sjúkraflutninga á Íslandi.

Við búum í einu strjálbýlasta landi heims og erfitt getur verið að halda uppi sjúkraflutningapjónustu í dreifðari byggðum. Sjúkraflutningamenn ganga par bakvaktir enda líður oft langur tími milli verkefna og erfitt að verja pað að hafa menn á bundinni vakt, pað er ekki hagkvæmt.

Á stærri stöðum er einnig leitað hagkvæmra leiða með pví að reka sjúkraflutninga og slökkvilið saman. Sjúkraflutningar eru par skilgreindir sem aukaverkefni og karpað og samið um pá á nokkurra ára fresti. Slökkvistarf er par í meginhlutverki og æðstu stjórnendurnir brunaverkfræðingar. Samt eru yfir $90 \%$ verkefna peirra sjúkraflutningar og flestir slökkviliðsmennirnir ekki síðri sem sjúkraflutningamenn.

Menntun sjúkraflutningamanna hefur tekið stórstígum framförum á undanförnum áratugum. Sjúkraflutningamenn eru ekki lengur bara sjúkrabílstjórar heldur heilbrigðisstarfsmenn með pjálfun í fyrstu viðbrögðum við slysum og bráðum veikindum. Grunnnámið hefur pó heldur dregist aftur úr viðmiðunarlöndum okkar í Evrópu, en pað er aðeins prjár vikur að lengd. Við bætist neyðarflutninganámskeið eftir priggja ára starfspjálfun og svo hafa nokkrir slökkviliðsmenn og aðrir áhugamenn farið í framhaldsnám á háskólastigi í Bandaríkjunum og menntað sig sem bráðatæknar.

Ráðgjafahópar og fagráð sjúkraflutninga hafa bent á nauðsyn pess að lengja menntun sjúkraflutningamanna til pess að efla sjúkraflutninga í landinu. Sjúkraflutningaskólinn er hins vegar rekinn á skólagjöldum einum saman og námið pví nokkuð dýrt. Pví er erfitt að sannfæra rekstraraðila sjúkraflutninga á smærri stöðum um að pað sé skynsamlegt að lengja námið, enda vinna starfsmenn peirra við sjúkraflutninga aðeins sem aukavinnu og erfitt að senda pá í langt og dýrt nám pegar peir hafa litlar tekjur af starfinu. Pá er orðið mál að framhaldsnámi í sjúkraflutningum verði komið á fót hér á landi, til pess að efla menntun sjúkraflutningamanna enn frekar. Aftur er pó er erfitt að sjá að menn frá smærri stöðunum sæki pað ef ekki eru í boði viðeigandi störf fyrir pá í heimabyggð.

Í fjársvelti undanfarinna ára hefur endurmenntun purft að víkja. Á mörgum stöðum kvarta sjúkraflutningamenn undan pví að engin endurmenntun sé í boði. Sjúkraflutningaskólinn, sem áður var rekinn að stórum hluta á endurmenntunarnámskeiðum, heldur nú ekki nema örfá slík. Pví veltir maður fyrir sér hvernig gangi að viðhalda pjálfun mannskaparins.

Líkt er farið með pá lækna sem purfa starfa sinna vegna stundum að mæta á vettvang slysa og bráðra veikinda. Nýleg könnun meðal peirra sýnir að oft er langt síðan heilsugæslulæknar hafa farið á námskeið í endurlífgun eða slysaviðbrögðum. Námskeiðið í bráðalækningum utan sjúkrahúsa (BLUS) sem fór svo vel af stað hér fyrir nokkrum árum og skerpti á viðbrögðum lækna við bráđum veikindum, endurlífgun, og slysum hjá bæði fullorðnum og börnum, hefur ekki verið haldið í nokkur ár.

Flutningar yfir lengri leiðir og við alvarleg veikindi fara oftast fram með flugi. Ein sjúkraflugvél er rekin hér á landi, með miðstöð á Akureyri. Sjúkraflutningamenn paðan sinna verkefnum pegar pau koma upp og taka með sér lækni af sjúkrahúsinu eða heilsugæslunni í alvarlegri tilfellum. Pó svo að landfræðilega mætti færa rök fyrir pví að einnig sé pörf fyrir allt að fjórar sjúkrapyrlur á Íslandi er engin slík starfrækt. Pess vegna er læknir (ennpá) hafður sem hluti af áhöfn pyrlu Landhelgisgæslunnar. Hlutverk pyrlunnar er að sinna björgun á sjó og landi og elta uppi veiðipjófa en einnig sinnir hún sjúkraflutningum við alvarleg slys og bráð veikindi. Rekstur björgunarpyrlna er mjög dýr, en nauðsynlegur. Ekki eru menn pó hafðir á bundinni vakt við sjúkraflug eða pyrlu og geta útköll pví hæglega tafist um dýrmætan hálftíma eða meira, á meðan menn eru að koma sér út á flugvöll og í gallana.

Erfitt getur reynst að átta sig á stjórnun og boðleiðum innan málaflokksins. Rekstrarlega heyra sjúkraflutningar undir fjölda mismunandi aðila. Ráðuneytið vill fela hverju umdæmi fyrir sig að skipuleggja sjúkraflutninga en tekur á sama tíma að sér að ákveða ýmis stærri og smærri atriði. Umsjónarlæknar eru svo í hverju heilbrigðisumdæmi og eiga að skipta sér af framkvæmd sjúkraflutninga. Yfirlæknirinn hefur svo umsjón með höfuðborgarsvæðinu, neyðarlínunni, pyrlunni og fleiru, til viðbótar faglegri yfirstjórn málaflokksins á landsvísu. Petta er honum ætlað að gera í hlutastarfi, sem er mjög í takt við rekstur sjúkraflutninga almennt. Hins vegar er erfitt að sjá hvernig hægt er að hafa umsjón með pessari starfsemi par sem sjúkraflutningaskýrslur færast ekki rafrænt og pví praktískt séð ómögulegt að halda utanum petta allt.

Eflum menntun sjúkraflutningamanna og eftirlit með peirra störfum, komum á bundnum vöktum fyrir sérhæfða pjónustu sjúkraflugs og pyrlu, og förum að taka sjúkraflutninga alvarlega sem mikilvægan hlekk í bráđapjónustu heilbrigðiskerfisins.

Emergency medical services in Iceland

Vidar Magnusson MD MBA National Director for Pre-hospital Emergency Services, Medical Director Capital District Fire and Rescue Service Emergency Department, Landspítalinn University Hospital Fossvogur, 108 Reykjavík, Iceland 